\title{
Burðarmálsdauði á Íslandi 1988-2017
}

\author{
Ragnhildur Hauksdóttir ${ }^{1,4}$ læknir \\ Pórður Pórkelsson ${ }^{1,2,3}$ læknir \\ Gestur Pálsson ${ }^{1,2,3}$ læknir \\ Ragnheiður I. Bjarnadóttiri,2,4 læknir
}

'Landspítali, ${ }^{2}$ æknadeild Háskóla Íslands, ${ }^{3}$ Barnaspítala Hringsins, ${ }^{4}$ kvennadeild Landspítala.

Fyrirspurnum svarar Ragnheiður I. Bjarnadóttir, ragnhib@landspitali.is

\section{Inngangur}

Burðarmál merkir tímabilið í kringum fæðinguna og er með burðarmálsdauða átt við fæðingu andvana barns eða dauða barns á fyrstu 7 dögunum eftir fæðingu. Andvana fædd börn voru áður aðeins talin með ef pau fæddust eftir 28+0 vikna meðgöngu (28+0: 28 vikna + 0 daga meðganga) eða voru að minnsta kosti $1000 \mathrm{~g}$ að pyngd við fæðingu væri meðgöngulengd ekki pekkt en annars talin til fósturláta. Árið 1994 var skilgreiningunni breytt og farið var að telja með andvana fædd börn eftir 22+0 vikna meðgöngu eða við $500 \mathrm{~g}$ fæðingarpyngd væri meðgöngulengd ekki pekkt. ${ }^{1-4}$ Nauðsynlegt er að taka tillit til pessara mismunandi skilgreininga pegar burðarmálsdauði er borinn saman milli landa eða tímabila. Tíðni burðarmálsdauða á Íslandi hefur verið ein sú allra lægsta í heiminum undanfarin ár. Fyrir tíma pessa rannsóknartímabils (1988-2017) hafði orðið mikil breyting á tíðni burðarmálsdauða, en frá árinu 1951 til og með 1980 hafði burðarmálsdauði lækkað úr 25,7 í 10,1 dauðsfall á hver púsund fædd börn., ${ }^{2,5-7}$

Frá miðri síðustu öld hafa verið settar fram ýmsar flokkanir á burðarmálsdauða, einkum með tilliti til orsaka. Í mörgum tilvikum stuðla fleiri en einn páttur, oft keðjuverkandi, að dauðsfalli og pví getur verið erfitt að skilgreina hvert tilfelli út frá einni dánarorsök. Раð er hins vegar mikilvægt að gera í faraldsfræðilegri úrvinnslu og nauðsynlegt til pess að hægt sé að gera samanburð milli tímabila og landa. Pannig má nota burðarmálsdauða sem mælikvarða á gæði heilbrigðispjónustu við burðarmál (perinatal care).3,8,9 Árið 1995 var búin til norræn-baltnesk flokkun (Nordic Baltic Perinatal Death Classification, NBPDC) með pað í huga að skilgreina pá flokka burðarmálsdauða sem hugsanlega væri hægt að fyrirbyggja (potentially avoidable) en ekki til að kanna orsakasamhengi. NBPDC flokkunin byggist á 5 breytum, mismikilvægum, en pær eru: Meðfæddur galli, hvenær í fæðingarferlinu barn deyr, vaxtarskerðing, meðgöngulengd og Apgarstig. Út frá pessum 5 breytum eru myndaðir 13 flokkar í NBPDC-flokkunarkerfinu. Petta kerfi hefur verið notað við flokkun burðarmálsdauða á Íslandi frá $19966^{1,3,8}$

Tilgangur rannsóknarinnar var að kanna tíðni burðarmálsdauða hér á landi árin 1988-2017, hvernig hún hefur breyst á

\begin{abstract}
Á G R I P
Inngangur

Með burðarmálsdauða er átt við fæðingu andvana barns eða dauða pess á fyrstu 7 dögunum eftir fæðingu. Tíðni burðarmálsdauða á Íslandi hefur verið ein sú allra lægsta í heiminum undanfarin ár. Markmið rannsóknarinnar var að kanna hvernig tíđni og orsakir burðarmálsdauða hafa breyst á síðastliðnum 30 árum, einkum til að meta hvort hugsanlega sé hægt að lækka tíðnina enn frekar.

\section{Efniviður og aðferðir}

Gerð var afturskyggn rannsókn og var rannsóknartímabilið 1988-2017. Upplýsingar um pau börn sem dóu á burđarmálsskeiði voru fengnar úr Fæðingaskrá og pau flokkuðð samkvæmt NBPDC-flokkunarkerfi, sem byggist á að skilgreina pá flokka burðarmálsdauða sem hugsanlega væri hægt að fyrirbyggja. Breyting á burðarmálsdauða var reiknuð út sem árleg prósentubreyting með Poisson-að̌hvarfsgreiningu.

\section{Nið̌urstöður}

Tíðni burðarmálsdauða lækkaði að meðaltali um 3,3\% $(p<0,001)$ á ári á tímabilinu miðað̃ við $\geq 28+0$ vikna meðgöngu. Börnum sem létust vegna meðfæddra galla fækkaði um $4,8 \%(p=0,001)$ á ári. Andvana fæðingum vaxtarskertra einbura eftir $\geq 28+0$ vikna meðgöngu fækkaði um $3,1 \%(p=0,029)$ á ári. Andvana fæðingum einbura eftir $\geq 28+0$ vikna meðgöngu sem voru ekki vaxtarskertir fækkaði ekki marktækt.
\end{abstract}

\section{Ályktun}

Tíðni burðarmálsdauða hefur lækkað umtalsvert síðastliðin 30 ár. Dauð̌sföllum vegna meðfæddra galla fækkaði mikið vegna framfara í fósturgreiningu. Andvana fæðingum vaxtarskertra barna hefur fækkað og hefur árvökul mæðravernd skipt par miklu máli. Erfiðast hefur reynst að fækka andvana fæddum einburum án áhættupátta eins og vaxtarskerðingar. Mikilvægt að fræða konur um pýðingu minnkaðra hreyfinga fósturs á međgöngu, hlusta á pær og rannsaka pegar ástæða pykir til.

doi.org/10.17992/lbl.2018.0708.193

tímabilinu og hvaða breyting hefur orðið í NBPDC-flokkum burðarmálsdauða á síðustu 30 árum.

\section{Efniviður og aðferðir}

\section{Burðarmálsdauði:}

Fæðing andvana barns eða dauðsfall pess á fyrstu viku eftir fæðingu. Fyrirburi:

Barn sem er fætt fyrir 37+0 vikna meðgöngu.

Um er að ræða afturskyggna rannsókn og var rannsóknartímabilið 1988-2017. Eftirfarandi upplýsingar voru fengnar úr Fæðingaskrá um börn sem fæddust andvana eða létust á fyrstu viku eftir fæðingu: Kyn barns, fæðingarstaður, hvort barnið var einburi eða fjölburi, lengd og höfuðummál við fæðingu, fæðingar- 
Tafla I. Breyting á NBPDC-flokkum burðarmálsdauða á tímabilinu. Flokkar IV og VII voru ekki taldir með par sem meðgöngulengd náði ekki 28+0 vikum í peim flokkum. Fjöldi tilfella (n) eru samanlögð tilfelli allt tímabilið i hverjum flokki.

\begin{tabular}{|c|c|c|c|c|}
\hline Númer flokks & NBPDC-flokkur & Fjöldi tilfella (n) & Árleg prósentubreyting (\%) (95\% Cl) & P-gildi \\
\hline I & Meðfæddur galli & 66 & $-4,8(-7,6$ til $-2,0)$ & 0,001 \\
\hline II & Fæðing andvana, vaxtarskerts einbura eftir $\geq 28+0$ vikna meðgöngu & 65 & $-3,1(-5,9$ til $-0,3)$ & 0,029 \\
\hline III & Fæðing andvana einbura eftir $\geq 28+0$ vikna meðgöngu & 216 & $-1,2(-2,7$ til 0,4$)$ & 0,138 \\
\hline V & Fæðing andvana fjölbura & 28 & $-5,0(-9,2$ til $-0,6)$ & 0,025 \\
\hline VI & Dauðsfall í fæðingu eftir $\geq 28+0$ vikna meðgöngu & 5 & $-5,1(-14,7$ til 5,6$)$ & 0,338 \\
\hline VIII & Dauðsfall nýbura (28+0 til 33+6 vikna meðganga), Apgar $\geq 7$ eftir 5 mínútur & 4 & $-13,2(-26,2$ til 2,1$)$ & 0,088 \\
\hline IX & Dauðsfall nýbura (28+0 til 33+6 vikna meðganga), Apgar $\leq 6$ eftir 5 mínútur & 13 & $-13,9(-21,6$ til $-5,5)$ & 0,002 \\
\hline$x$ & Dauð̌sfall nýbura eftir $\geq 34+0$ vikna meðgöngu, Apgar $\geq 7$ eftir 5 mínútur & 11 & $-4,4(-11,0$ til 2,6$)$ & 0,214 \\
\hline $\mathrm{XI}$ & Dauð̌sfall nýbura eftir $\geq 34+0$ vikna meðgöngu, Apgar $\leq 6$ eftir 5 mínútur & 26 & $-5,6(-10,0$ til $-1,0)$ & 0,017 \\
\hline XII & Dauðsfall nýbura fyrir 28+0 vikna meðgöngu & 108 & $-4,0(-6,1$ til $-1,8)$ & $<0,001$ \\
\hline XIII & Óflokkað & 2 & $-1,2(-15,8$ til 16,0$)$ & 0,884 \\
\hline
\end{tabular}

pyngd, Apgarstig barns við eina og fimm mínútur, lengd meðgöngu, hvenær barn dó (meðgöngulengd eða aldur), sjúkdómsgreiningar móður og sjúkdómsgreiningar barns.

Börnin voru síðan flokkuð samkvæmt NBPDC-flokkunarkerfinu, sjá töflu I. Andvana fætt barn var talið vaxtarskert ef pað var undir 10. hundraðshluta (percentile) mörkum á vaxtarriti á barnablaði Landspítala. Hvert barn gat aðeins verið í einum flokki og var meðfæddur galli ráðandi, hafi hann verið talinn alvarlegur eða banvænn.

Upplýsingar um fæðingar andvana barna fyrir 28+0 vikna meðgöngu vantar fyrir árin 1988-1993 svo miðað er við að minnsta kosti 28+0 vikna meðgöngu pegar breytingar á öllu 30 ára tímabilinu eru bornar saman. Flokkar IV og VII í NBPDC-flokkunarkerfinu telja andvana fædd börn fyrir $28+0$ vikna meðgöngu annars vegar og börn dáin í fæðingu fyrir 28+0 vikna meðgöngu hins vegar og eru peir pví ekki bornir saman innan tímabilsins. Upplýsingar um fjölda lifandi og andvana fæddra barna fengust á heimasíðu Hagstofu Íslands.

Öll gögn voru færð inn í Microsoft Excel töflureikni. Við úrvinnslu gagna var notast við tölfræðiforritið Stata 13. Poisson-aðhvarfsgreining var notuð til að reikna út leitni (trend) fyrir burðarmálsdauða á tímabilinu. Reiknuð var út árleg prósentubreyting

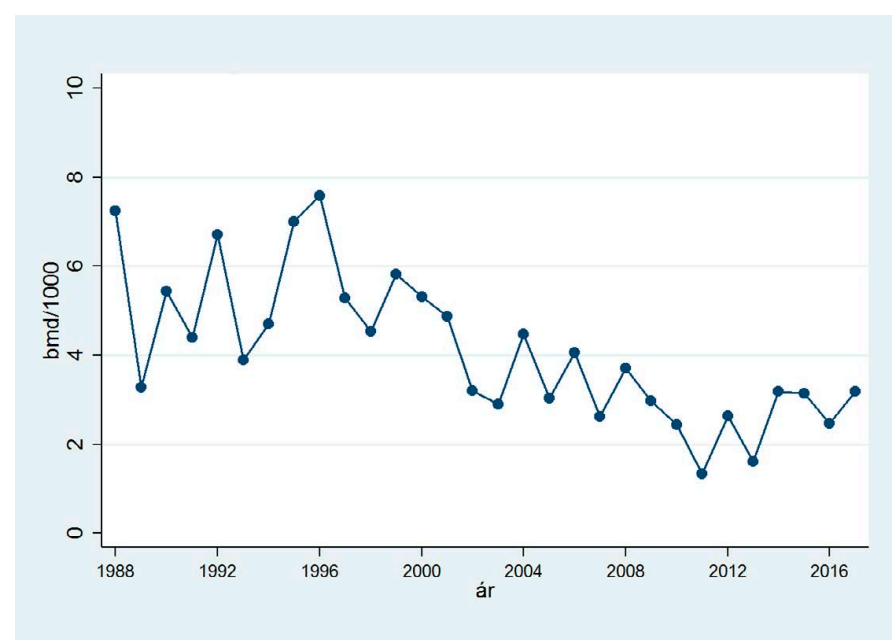

Mynd 1. Burðarmálsdauði á hverja 1000 fædda miðað við 28+0 vikna meðgöngu á Íslandi 1988-2017. fyrir burðarmálsdauða og hvern NBPDC-flokk út frá nýgengihlutfalli (incidence rate ratio, IRR) úr Poisson-aðhvarfsgreiningu, sem einnig má túlka sem áhættuhlutfall. ${ }^{10}$ Svarbreyta/háð breyta var fjöldi burðarmálsdauðsfalla og skýribreytur/óháđar breytur voru tími (ár) og NBPDC-flokkur. Útsett breyta var fjöldi lifandi og andvana fæddra á hverju ári. Líkanagreining gaf til kynna að líkanið var viðeigandi fyrir gögnin.

Tölfræðileg marktækni var miðuð við $\alpha$ (alpha) 0,05 og var 95\% öryggisbil (confidence interval, CI) reiknað. Dánartíðni er gefin upp sem fjöldi á hverja 1000 andvana og lifandi fædda á viðkomandi tímabili.

Öll tilskilin leyfi fyrir rannsókninni fengust hjá vísindasiðanefnd, Persónuvernd og framkvæmdastjóra lækninga Landspítala. Embætti landlæknis veitti aðgang að gögnum úr Fæðingaskrá.

\section{Niðurstöður}

Á rannsóknartímabilinu dóu 544 börn á burðarmálsskeiði ef andvana fædd börn voru meðtalin eftir $\geq 28+0$ vikna meðgöngu. Ef börn andvana fædd eftir $\geq 22+0$ vikna meðgöngu voru talin með dóu 537 börn á árunum 1994-2017. Tíðni burðarmálsdauða lækkaði

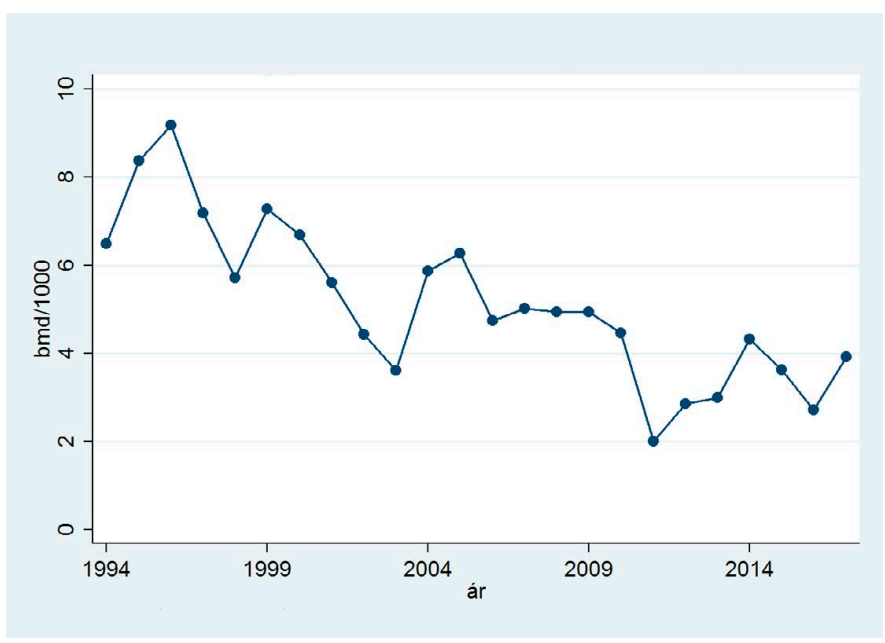

Mynd 2. Burðarmálsdauði á hverja 1000 fædda miðað við 22+0 vikna meðgöngu á Íslandi 1994-2017. 


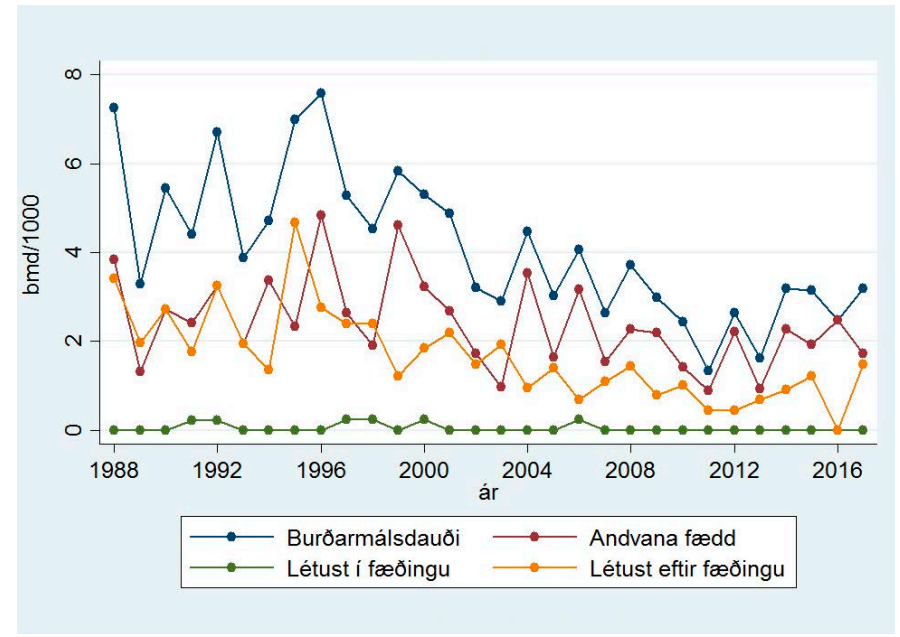

Mynd 3. Burðarmálsdauði miðað við 28+0 vikna meðgöngu (bláa línan) og hvernig hann skiptist niður eftir poí hvenær börnin dóu.

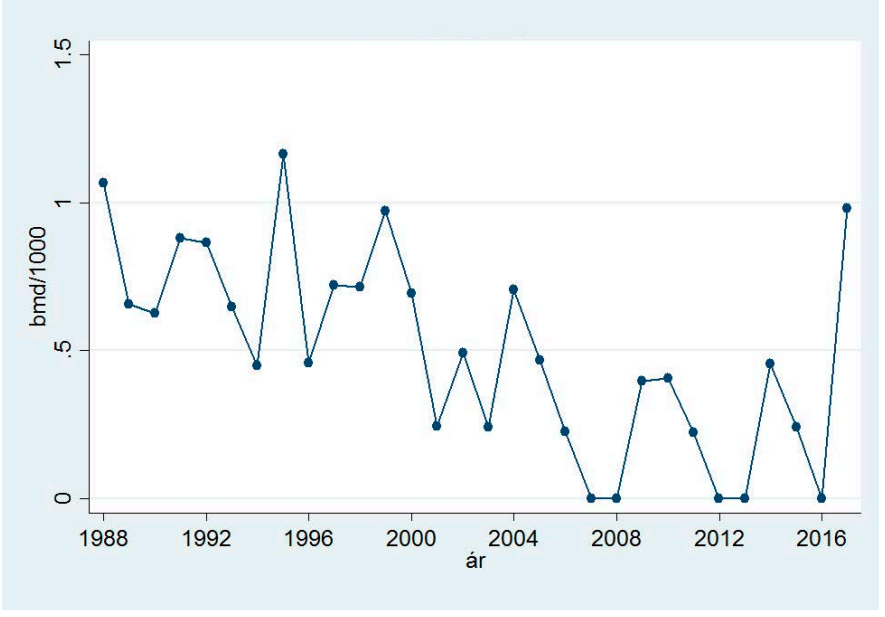

Mynd 4. Burðarmálsdauði vegna meðfæddra galla (flokki I) á tímabilinu.

að meðaltali um 3,3\% (95\% CI -4,2 til -2,3, p<0,001) á ári á tímabilinu miðað við $\geq 28+0$ vikna meðgöngu (mynd 1). Tíðni burðarmálsdauða lækkaði að meðaltali um 4,1\% (95\% CI -5,3 til -2,9, p<0,001) á ári á árunum 1994-2017 miðað við $\geq 22+0$ vikna meðgöngu (mynd 2). Fjölda barna sem dóu burðarmálsdauða á hverja 1000 lifandi og andvana fædda hvert ár frá 1988 til 2017 má sjá í töflu II.

Peim börnum sem fæddust andvana fækkaði um 1,9\% á ári á tímabilinu (95\% CI -3,2 til -0,7, p=0,003). Börnum sem létust eftir fæðinguna fækkaði meira, eða um 5,1\% á ári á tímabilinu (95\% CI 6,6 til -3,6, p<0,001). Ekki varð marktæk fækkun á peim börnum sem dóu í fæðingu (-6,9\%,95\%CI -16,0 til 3,1, p=0,169) (mynd 3).

Niðurstöður - flokkar burðarmálsdauða

Öll börn sem dóu burðarmálsdauða voru flokkuð í 13 flokka eftir NBPDC-flokkunarkerfinu og árleg prósentubreyting reiknuð út (tafla I). Breytingar sem urðu á tímabilinu í flokkum I, II, III og XII má sjá á myndum 4, 5, 6 og 7 .

\section{Umræður}

Burðarmálsdauði lækkaði umtalsvert á rannsóknartímabilinu, hvort sem miðað er við 22+0 eða 28+0 vikna meðgöngulengd and-

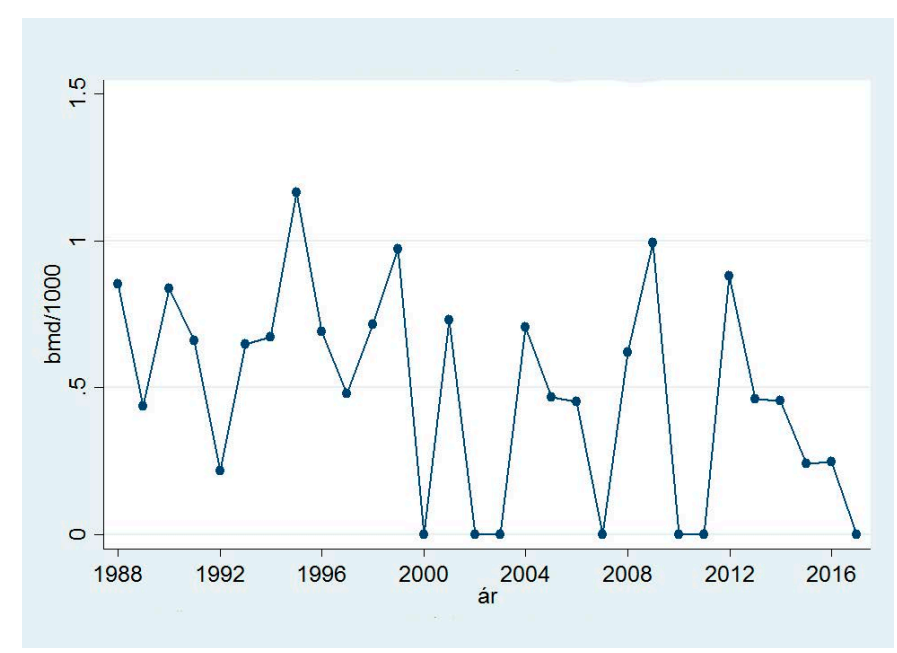

Mynd 5. Fæðingar andvana vaxtarskertra einbura eftir 28+0 vikna meðgöngu (flokki II) á tímabilinu.

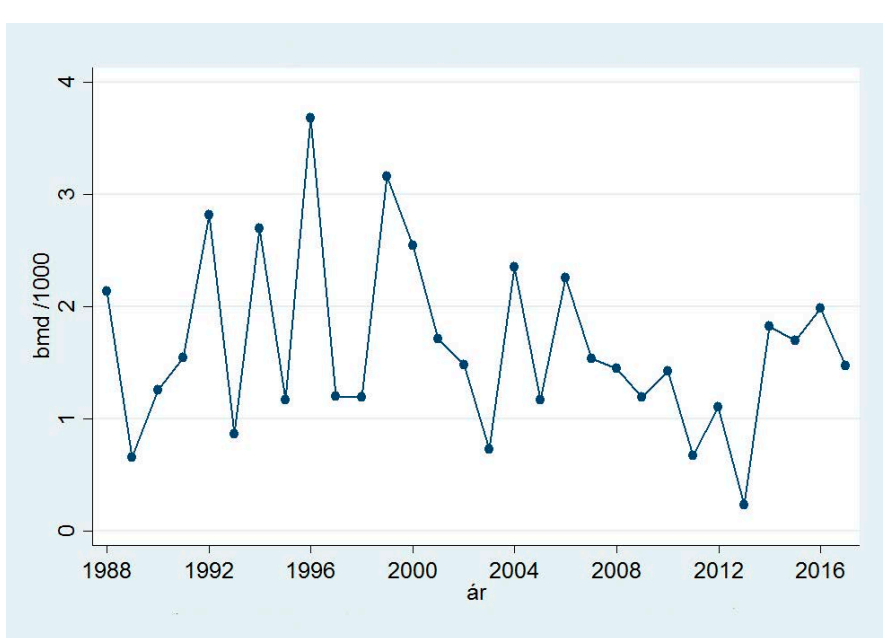

Mynd 6. Fæðingar andvana einbura sem ekki voru vaxtarskertir efitr 28+0 vikna meðgöngu (flokki III).

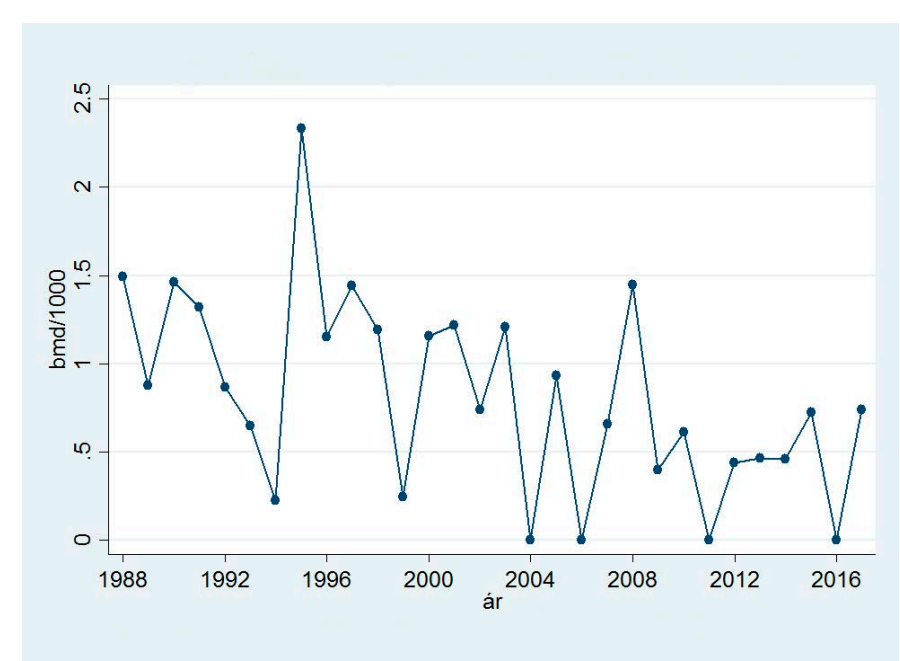

Mynd 7. Dauðsföll nýbura fyrir 28+0 vikna meðgöngu á fyrstu viku eftir fæðingu (flokki XII).

vana fæddra barna. Pegar skoðað er hvenær á burðarmálsskeiði börnin dóu (mynd 3) kemur í ljós að peim börnum sem létust eftir fæðinguna fækkaði meira en peim sem fæddust andvana. Dauðsföll í fæðingu voru mjög fá allt rannsóknartímabilið. 
Tafla II. Burðarmálsdauði 1988-2017. Fjöldi barna á hverja 1000 fædda sem dóu burðarmálsdauða á hverju ári 1988-2017.

\begin{tabular}{|c|c|c|}
\hline Ár & $\begin{array}{l}\text { Burðarmálsdauði } \\
\text { (miðað við 22+0 vikur) }\end{array}$ & $\begin{array}{c}\text { Burðarmálsdauði } \\
\text { (miðað við 28+0 vikur) }\end{array}$ \\
\hline 1988 & - & 7,2 \\
\hline 1989 & - & 3,3 \\
\hline 1990 & - & 5,8 \\
\hline 1991 & - & 4,4 \\
\hline 1992 & - & 6,7 \\
\hline 1993 & - & 3,9 \\
\hline 1994 & 6,5 & 4,7 \\
\hline 1995 & 8,4 & 7,0 \\
\hline 1996 & 9,2 & 7,6 \\
\hline 1997 & 7,2 & 5,3 \\
\hline 1998 & 5,7 & 4,5 \\
\hline 1999 & 7,3 & 6,1 \\
\hline 2000 & 6,7 & 5,3 \\
\hline 2001 & 5,6 & 4,9 \\
\hline 2002 & 4,4 & 3,2 \\
\hline 2003 & 3,6 & 1,0 \\
\hline 2004 & 5,9 & 4,5 \\
\hline 2005 & 6,3 & 3,0 \\
\hline 2006 & 4,7 & 4,1 \\
\hline 2007 & 5,0 & 2,6 \\
\hline 2008 & 5,0 & 3,7 \\
\hline 2009 & 5,0 & 3,0 \\
\hline 2010 & 4,5 & 2,8 \\
\hline 2011 & 2,0 & 1,3 \\
\hline 2012 & 2,9 & 2,6 \\
\hline 2013 & 3,0 & 1,6 \\
\hline 2014 & 3,2 & 4,3 \\
\hline 2015 & 3,1 & 3,6 \\
\hline 2016 & 2,5 & 2,7 \\
\hline 2017 & 3,4 & 3,9 \\
\hline
\end{tabular}

\section{Flokkur I- meðfæeddur galli}

Umtalsverð og marktæk fækkun varð á dauðsföllum vegna meðfæddra galla (mynd 4). Augljós skýring er bætt fósturgreining á tímabilinu, og í kjölfarið meðgöngurof, ef gallinn var talinn ólífvænlegur. Á árunum 1984-1986 var 18-20 vikna ómskoðun orðin almenn hér á landi. Ómskoðun er nú viðurkennd sem árangursrík aðferð til að meta meðgöngulengd og fylgjustaðsetningu og greina fleirbura og fósturgalla. ${ }^{11}$ Við meðgöngurof er verið að afstýra fæðingu barns sem hefði líklega dáið á meðgöngu eða skömmu eftir fæðinguna eða búið við mikla fötlun. Fósturgreining getur einnig gagnast okkur á annan hátt. Betri meðferð vegna meðfæddra galla hefur vissulega haft áhrif til lækkunar burðarmálsdauða par sem nú er hægt að gera við ýmsa galla sem áður drógu börn til dauða, til dæmis pindarhaulsslit (congenital diaphragmatic hernia, $\mathrm{CDH}$ ) og ýmsa hjartagalla. Í peim tilfellum er mikilvægt að réttur viðbúnaður sé til staðar við fæðingu barns par sem fyrsta meðferð eftir fæðingu getur skipt sköpum fyrir barnið og pví getur greining fósturgalla fyrir fæðingu aukið lífslíkur barnsins. ${ }^{11,12}$

\section{Flokkar II, III og V-frðing andvana barns}

Marktæk fækkun varð í flokki andvana fæddra vaxtarskertra einbura (flokki II, mynd 5). Pegar NBPDC-flokkunarkerfið var sett fram voru ákveðnir flokkar skilgreindir sem flokkar dauðsfalla sem hugsanlega væri hægt að afstýra. Flokkur andvana fæddra, vaxtarskerta einbura er einn peirra en hinir eru flokkar VI og VIII (dauðsfall í fæðingu eftir $\geq 28+0$ vikna meðgöngu og dauðsfall nýbura (28+0 til 33+0 vikna meðganga) með Apgar-stig $\geq 7$ eftir 5 mínútur). ${ }^{3}$ Pessi fækkun getur meðal annars bent til að árvekni hafi aukist í mæðravernd en pannig ætti að vera hægt að greina vaxtarskerðingu fósturs, auka eftirlit og ljúka meðgöngu fyrr ef merki er um alvarlega fylgjupurrð og pannig mögulega afstýra andvana fæðingu.

Stór hluti burðarmálsdauðsfalla fellur undir flokk andvana fæddra einbura sem ekki eru vaxtarskertir (flokk III). Ekki varð marktæk fækkun í peim flokki (mynd 6) enda er erfitt að greina og sjá pau dauðsföll fyrir par sem fátt eða ekkert gefur til kynna að ekki sé allt með felldu hjá fóstri eða í fylgju. Einnig er vert að benda á að hluti dauðsfalla andvana fæddra barna sem ekki eru vaxtarskert er líklega til kominn sem afleiðing einhvers konar slyss, til dæmis tilfallandi klemmu á naflastreng og pví ekki auðvelt að sjá fyrir. ${ }^{3}$

Marktæk fækkun varð einnig í flokki andvana fæddra fjölbura (flokki V) en par skiptir eftirlit á meðgöngu miklu máli en konur sem ganga með fjölbura eru oft í áhættumæðravernd par sem grannt er fylgst með peim.

Flokkar VI og XI - dauðsföll í eða eftir fæðingu vegna fósturköfnunar Ekki varð marktæk breyting á fjölda dauðsfalla í fæðingu (flokki VI) enda mjög fá tilfelli í peim flokki allt tímabilið. Hins vegar varð marktæk fækkun í flokki nýbura sem fæddir voru eftir $\geq 34+0$ vikna meðgöngu og með Apgar $\leq 6$ eftir 5 mínútur (flokki XI). Pessir tveir flokkar telja börn sem dóu í eða eftir fæðingu, líklega vegna súrefnispurrðar. ${ }^{3}$ Pessi dauðsföll voru fátíð á rannsóknartímanum en pau endurspegla gæði eftirlits í fæðingu og fæðingarhjálpar. Í peim löndum par sem eftirliti í fæðingu og fæðingarhjálp er ábótavant eru dauðsföll sem pessi algengari. ${ }^{13}$ Fyrir 1970, eða áður en keisaraskurðir urðu almennir hér á landi, var súrefnisskortur aðalorsök burðarmálsdauða. ${ }^{14,15}$ Síðan hefur tíðni keisaraskurða prefaldast. ${ }^{6}$ Ástæður aukins fjölda peirra eru ýmsar en aðgerðin er oftast framkvæmd með pað í huga að minnka hættu á fylgikvillum hjá barni, vegna meðgöngusjúkdóma eða vegna gruns um fósturstreitu fyrir eða í fæðingu. Pví mætti halda að aukin tíðni keisaraskurða skilaði sér í lækkun burðarmálsdauða. Íslensk rannsókn, sem gerð var í peim tilgangi að meta hugsanleg tengsl keisaraskurða við burðarmálsdauða hjá einburum sem vógu $\geq 2500$ g við fæðingu á árunum 1982-2003, sýndi hins vegar ekki fram á 
marktæka fækkun dauðsfalla hjá pessum hópi barna. ${ }^{14}$ Pað leiðir hugann að pví hvort um sé að ræða einhvers konar „,pröskuld“, pað er að keisaraskurðir geti fækkað tilfellum fósturköfnunar upp að einhverju marki en fyrirbyggi ekki dauðsföll. Verðugt verkefni er að fækka enn frekar dauðsföllum fullburða, heilbrigðra barna sem deyja af völdum fósturköfnunar. Stærsti vandinn par er að finna jafnvægið á milli hæfilegs eftirlits og hæfilegra inngripa í fæðingu. Pau Evrópulönd sem hafa hæstu tíðni keisaraskurða hafa einnig hæstu tíðni burðarmálsdauða. Ísland og hin Norðurlöndin hafa hins vegar bæði lága tíðni keisaraskurða og burðarmálsdauða. ${ }^{5}$

Flokkur XII - dauðsfall nýbura fyrir 28+0 vikna meðgöngu

Flest peirra barna sem dóu á fyrstu viku eftir fæðingu voru nýburar fæddir fyrir 28+0 vikna meðgöngu (flokkur XII) en marktæk lækkun varð í peim flokki á tímabilinu (mynd 7). Sýnir petta betri lifun minnstu fyrirbura, sem er eflaust vegna framfara í nýburalækningum sem urðu á tímabilinu, en par má nefna betri öndunarvélameðferð og lungnablöðruseyti (surfactant) sem var farið að nota um 1990 sem lyf við glærhimnusjúkdómi, en um svipað leyti var einnig farið að gefa konum í yfirvofandi fyrirburafæðingu barkstera til að flýta fyrir proska lungna fóstursins. ${ }^{16}$

Fá börn voru í öđrum flokkum barna sem dóu á fyrstu viku eftir fæðingu (flokkar VIII - X).

\section{Getum við gert betur?}

prátt fyrir að tíðni burðarmálsdauða sé með pví lægsta sem pekkist í heiminum er æskilegt að geta gert enn betur. Ljóst er af framanskráðu að íslenskt heilbrigðisstarfsfólk hefur á valdi sínu tækni og pekkingu til að gera vel hvað burðarmálsdauða varðar. En hvernig getum við bætt árangurinn enn frekar? Seint verður hægt að bjarga öllum börnum. Nú greinast langflestir ólífvænlegir fósturgallar á meðgöngu, lifun minnstu fyrirburanna hefur aukist mikið og dauðsföll í fæðingu eða skömmu eftir hana vegna súrefnisskorts eru orðin mjög fátíð. Sá flokkur sem ennpá er stærstur er flokkur III í NBPDC-flokkuninni, flokkur andvana fæddra einbura eftir $\geq 28+0$ vikna meðgöngu sem eru án greinilegra áhættupátta eins og vaxtarskerðingar, en hann er erfiðast að greina. Pá er mikilvægt að hlusta á pær konur sem láta vita af minnkuðum hreyfingum fósturs og rannsaka pær og fóstrið í kjölfarið en minnkaðar hreyfingar geta verið merki um undirliggjandi vandamál í allt að fjórðungi tilvika pótt algengasta ástæðan sé, sem betur fer, sofandi fóstur. Rannsóknir hafa sýnt fram á pað að með pví að fræða konurnar koma pær fyrr en ella í skoðun vegna minnkaðra hreyfinga og pá er oftast meiri tími til að grípa inn í purfi pess, en komum fjölgar ekki mikið. Fræðsla um pýðingu minnkaðra hreyfinga er pví mikilvægur liður í mæðravernd..$^{17,18}$

Hversu langt á að ganga? Með öndunarvélum og annarri nútímatækni er hægt að halda lífi í alvarlega veikum börnum. En er pað alltaf réttlætanlegt? Í lögum um réttindi sjúklinga er kveðið á um að sjúklingur eigi rétt á fullkomnustu heilbrigðispjónustu sem á hverjum tíma er völ á að veita. ${ }^{19}$ Jafnframt segja siðareglur lækna að peir eigi að hafa velferð sjúklings að leiðarljósi. ${ }^{20}$ Eigum við að gera allt sem í okkar valdi stendur til að halda á lífi nýbura sem mun að öllum líkindum búa við mikla fötlun? Hér verður að meta hvert og eitt tilfelli fyrir sig og er eðlilegt að foreldrar séu með í ráðum.

\section{Styrkleikar og takmarkanir rannsóknarinnar}

Helsti styrkleiki pessarar rannsóknar er að hún tekur til heillar pjóðar. Rannsóknartímabilið er langt, nær yfir 30 ár og gefur rannsóknin pví góða mynd af breytingum sem urðu á tímabilinu. Einn og sami rannsóknaraðili (fyrsti höfundur) fór yfir öll gögn og skráði upplýsingar og náðist með pví gott innra samræmi. Aðrir höfundar gáfu sérfræðiálit. Einn veikleiki rannsóknarinnar er að hún er afturskyggn og pví háo réttmæti og nákvæmni sjúkraskráningar á hverjum tíma. Annar veikleiki sem vert er að nefna er að á fyrstu árum rannsóknartímabilsins voru andvana fædd börn aðeins talin með ef pau fæddust eftir 28+0 vikna meðgöngu (eða voru að minnsta kosti $1000 \mathrm{~g}$ að pyngd við fæðingu væri meðgöngulengd ekki pekkt) en annars talin til fósturláta. Pví var ekki hægt að bera burðarmálsdauða saman eins og hann er skilgreindur nú, pað er miðað við andvana fædd börn eftir 22+0 vikna meðgöngu (eða við $500 \mathrm{~g}$ fæðingarpyngd sé meðgöngulengd ekki pekkt).

\section{Pakkir}

Pakkir fá Eva Jónasdóttir fæðinga- og kvensjúkdómalæknir, Guðrún Garðarsdóttir ritari Fæðingaskrár, Ubaldo Benitez Hernandez tölfræðingur og Póra Steingrímsdóttir fæðinga- og kvensjúkdómalæknir. 


\section{Heimildir}

1. Bjarnadóttir RI. Burðarmálsdauði á Íslandi - getum við enn lækkað tíðnina? Læknablaðið 2003; 89: 745-6.

2. Biering G, Snædal G, Sigvaldsson H, Ragnarsson J. Fæðingar á Íslandi 1972-1981, 10. grein: Meðganga og burðarmálsdauði. Nokkrir áhættupættir. Læknablaðið 1983; 69: 359-62.

3. Bjarnadóttir RI, Geirsson RT, Pálsson G. Flokkun burðarmálsdauða á Íslandi 1994-1998. Læknablaðið 1999; 85 981-6.

4. ICD-10. International Statistical Classification of Diseases and Related Health Problems. Instruction manual. Vo 2. 10th revision ed. Geneva: World Health Organization 2016.

5. EURO-PERISTAT Project with SCPE and EUROCAT. European Perinatal Health Report. The health and care of pregnant women and babies in Europe in 2010. europeristat.com - júní 2018 .

6. Fæðingaskrá. landlaeknir.is/tolfraedi-og-rannsoknir/ gagnasofn/gagnasafn/item12340/Faedingaskra.

7. http://ec.europa.eu/eurostat/data/database?node_ code=demo_minfind - júní 2018
8. de Galan-Roosen AE, Kuijpers JC, van der Straaten PJ, Merkus JM. Fundamental classification of perinatal death. Validation of a new classification system of perinatal death. Eur J Obstet Gynecol Rep Biol 2002; 103: 30-6.

9. Winbo IG, Serenius FH, Dahlquist GG, Kallen BA. NICE, a new cause of death classification for stillbirths and neonatal deaths. Neonatal and Intrauterine Death Classification according to Etiology. Int J Epidemiol 1998; 27: 499-504.

10. Hernán MA. The Hazards of Hazard Ratios. Epidemiol 2010; 21: 13-5.

11. Geirsson RT. Ómskoðun við 18-20 vikur. Læknablaðið 2001; 87: 403-7.

12. Helgason H. Fósturgreining, fyrir hverja? Læknablaðið 2001: 87: 395-6.

13. Lawn JE, Kerber K, Enweronu-Laryea C, Cousens S. 3.6 million neonatal deaths--what is progressing and what is not? Sem Perinatol 2010; 34: 371-86.

14. Jónsdóttir G, Bjarnadóttir RI, Geirsson RT, Smárason A. Eru tengsl á milli tíðni keisaraskurđa og burđarmálsdauða á Íslandi undanfarin 15 ár? Læknablaðið 2006; 92: 191-5.
15. Johnsen B. Orsakir burðarmálsdauða á Íslandi 1955-1976. Læknablaðið 1983; 69: 191-8.

16. Pórkelsson P. Lífslíkur fyrirbura. Læknablaðið 2009; 95 : 105.

17. Tveit JVH, Saastad E, Stray-Pedersen B, Børdahl PE, Flenady V, Fretts R, et al. Reduction of late stillbirth with the introduction of fetal movement information and guidelines - a clinical quality improvement. BMC Pregnancy Childbirth 2009; 9: 32 .

18. Heazell AEP, Weir CJ, Stock SJE, Calderwood CJ, Burley SC, Froen JF, et al. Can promoting awareness of fetal movements and focusing interventions reduce fetal mortality? A stepped-wedge cluster randomised trial (AFFIRM). BMJ Open 2017; 7:e014813.

19. Lög um réttindi sjúklinga. althingi.is/lagas/123a/1997074. html1999 - júní 2018.

20. Siðareglur lækna. landlaeknir.is/gaedi-og-eftirlit/heilbrigdisstarfsfolk/starfsleyfi/sidareglur/item13353/ - júní 2018

Barst til blađsins 25. október 2017, sampykkt til birtingar 26. júní 2018.

\section{Perinatal mortality in Iceland 1988-2017}

\author{
Ragnhildur Hauksdóttir ${ }^{1,4}$ \\ Pórður Pórkelsson ${ }^{1,2,3}$ \\ Gestur Pálsson ${ }^{1,2,3}$ \\ Ragnheiður I. Bjarnadóttir ${ }^{1,2,4}$
}

\section{Introduction}

Perinatal mortality refers to stillbirth and neonatal death during the first week of life. Recently perinatal mortality rate in Iceland has been among the lowest in the world. The aim of the study was to evaluate how perinatal mortality rate and its causes have changed in Iceland during the last 30 years, particularly to see if it is possible to lower the perinatal mortality rate even more.

\section{Cases and methods}

The study was retrospective and included all infants that were stillborn or died during the first week of life in 19882017. Information was obtained from the Icelandic Medical Birth Registry, the annual reports on births in Iceland. A classification focusing on identifying groups of perinatal death that are potentially avoidable was used. An annual percent change was calculated with Poisson regression.

\section{Results}

The perinatal mortality rate declined on average by $3,3 \%$ per year in the period based on $\geq 28+0$ weeks gestation. The number of infants that died because of congenital anomalies decreased on average by $4,8 \%$ per year. The number of growth restricted stillborn singletons after $\geq 28+0$ weeks of gestation decreased on average by $3,1 \%$ per year. The number of non growth restricted stillborn singletons after $\geq 28+0$ weeks of gestation did not decrease significantly.

\section{Conclusion}

Perinatal mortality rate has declined substantially in Iceland during 30 years. Deaths because of congenital anomalies have decreased considerably due to improvement in prenatal diagnosis. Stillbirths associated with growth restriction have decreased but stillbirths that are not associated with growth restriction have not. Thus it is important to emphasize that women seek medical attention when they experience decreased fetal movements.

'Landspitali University Hospital, ${ }^{2}$ Faculty of Medicine - University of Iceland, ${ }^{3}$ Childrens hospital - Landspitali University Hospital, ${ }^{4}$ department of obstetrics and gynecology - Landspitali University Hospital.

Key words: perinatal mortality, stillbirth, congenital anomaly, asphyxia, Nordic Baltic Perinatal Death Classification. 